\title{
THE MEANING OF DIASPORIC IDENTITY: A Case of Indonesian Community Overseas
}

\author{
Irin Oktafiani \\ Research Center for Population \\ Indonesian Institute of Sciences, Jakarta, Indonesia \\ Email: irin.oktafiani@gmail.com
}

\begin{abstract}
This paper argues that the term of the diaspora in Indonesia has been transformed and simplified from the general diaspora concept and its conceptual meaning is not enough to define the Indonesian diaspora. The Indonesian government have already made a clear characteristic of Indonesian diaspora through the Presidential Regulation No. 76 of 2017 , it is stated implicitly that Indonesian diaspora is whoever living abroad, despite they only live there for a short period. Regardless of what the Indonesian government has done to define the meaning of the diaspora, the definition is not enough to explain about Indonesian diaspora. By any conditions, the Indonesian government could not neglect the history of some Indonesian political refugees in 1965 or 1998 since there was a painful history left behind and it is unsure whether they want to recognize themselves again as Indonesia. On the other hand, the second generation or more of Indonesian who already got another country citizenship, can not be guaranteed to have a sense of belonging with Indonesia and want to recognize that they have Indonesian descent. This paper will elucidate what really matters in the term of Indonesian diaspora in the sense of belonging and the confession that they are being attached to Indonesia.
\end{abstract}

Keywords: diaspora, Indonesia, recognition, sense of belonging

\begin{abstract}
Abstrak
Makalah ini memperlihatkan bahwa istilah diaspora di Indonesia telah bertransformasi dan disederhanakan dari konsep diaspora umum dan makna konseptualnya tidak cukup untuk mendefinisikan diaspora Indonesia. Pemerintah Indonesia telah membuat karakteristik yang jelas dari diaspora Indonesia melalui Peraturan Presiden No. 76 tahun 20I7, dinyatakan secara implisit bahwa diaspora Indonesia adalah siapa pun yang tinggal di luar negeri, meskipun mereka hanya tinggal di sana dalam waktu singkat. Terlepas dari apa yang telah dilakukan pemerintah Indonesia untuk mendefinisikan makna diaspora, definisi tersebut tidak cukup untuk menjelaskan tentang diaspora Indonesia. Dengan kondisi apa pun, pemerintah Indonesia tidak dapat mengabaikan sejarah beberapa pengungsi politik Indonesia pada tahun 1965 atau 1998 karena terdapat sejarah menyakitkan yang tersisa dan tidak dapat dipastikan apakah pengungsi tersebut ingin mengenali diri mereka lagi sebagai orang Indonesia atau tidak. Di sisi lain, generasi kedua atau lebih perantauan Indonesia yang sudah mendapat kewarganegaraan negara lain, tidak dapat dijamin bahwa mereka masih punya rasa memiliki terhadap keindonesiaan-nya dan ingin mengakui bahwa mereka memiliki keturunan Indonesia. Makalah ini menjelaskan apa yang penting dalam istilah diaspora Indonesia dalam hal rasa memiliki dan pengakuan bahwa mereka terikat pada Indonesia.
\end{abstract}

Kata kunci: diaspora, Indonesia, pengakuan, rasa memiliki 


\section{INTRODUCTION}

Some scholars had seen diaspora from the perspective of identity and community relations. One example is Zigmunt Baumann (1989) who had seen a feature of antisemitism related to diaspora phenomenon of Jews which lead to the value of racism, morality, and modernity. Baumann argued that there was a community relation of Jews diaspora, which mold an opposition identity between 'us' and 'others' with the other ethnicity, who eventually led them into the holocaust. Another example is Bugis diaspora in Sabah, which seen as the culture identity and the migration phenomenon (Zaenuddin, et al., 20II). The Bugis diaspora migrated to Sabah in the igth century, and they were able to adapt well with the locals. However, they still keep their identity by joining the community group of South Sulawesi people in order to avoid an internal conflict.

Nowadays, diaspora can be seen wider not only related to community. It is believed that the existence of diaspora has remained a big potential to develop a country, this is due to many people in the diaspora is a full time-high-skilled workers. Scholars have seen two perspective of it, which are return option and diaspora option. The return option is a strategy to bring skilled migrants back to their origin country and the diaspora option offers an indirect mobilization of expatriate association, so that professionals can still live at their current resident (Ite, 2002). In 2016, The President of Republic Indonesia, Joko Widodo, had tried the return option by asking 24 Indonesian professors who stayed in The United States of America to return and help the government to develop West Papua. Furthermore, specifically, the president asked Arcandra Tahar, a professional engineer, to come back and become the Indonesian Minister of Energy and Mineral Resouce.

Regardless of all options to develop Indonesia, the government needed to identify who is diaspora and the categorization of it. By the law, the Indonesian government had declared a categorization of Indonesian diaspora implicitly. Stated in the 20I7 Presidential Regulation No. 76, Indonesian diaspora is categorized into three different statuses, those are, Indonesian citizens who live overseas, foreigner ancestry, and Indonesian who decided to become a foreigner. The categorization from the government is clear but it is raising some questions. First, are the people whom fitted in with the criteria certainly want to recognize themselves as Indonesian diaspora? What is the meaning of Indonesian diaspora by them and by the other Indonesians within the country?; Is it true that the Indonesian diaspora can be used for development? Furthermore, what kind of contribution they can do for Indonesia?

To analyze the meaning of Indonesian diaspora, first, this paper compared the Indonesian categorization of diaspora from the 2017 Presidential Regulation No. 76 with the 4 characteristics of diaspora from Butler (20II). Butler stated that diaspora has four characteristics, which are (I) have two or more spreading location, (2) has a relation with the homeland, either imagined or actual, (3) has a sense of belonging in the group. The last is (4) historical-temporal dimension, which is the existence of the group is minimum for two generations. Therefore, this paper argues that there is a different point of view to see diaspora with formal regulation and actual fact. The second this paper describes the recognition of Indonesian diaspora and how the acceptance of Indonesian people if the diaspora are asked to return. The last, the paper explains that what kind of action from the Indonesian diaspora can do in order to support the development.

\section{THE CHARACTERISTICS AND CONCEPT DEVELOPMENT OF DIASPORA IN THE WORLD}

Initially, the concept of diaspora refers to the distribution of Jews from their native regions caused by forced displacement (Wahlbeck, 2000: 229). In general, the concept of diaspora refers to displacement that can be said to be forced, the existence of scattered settlements, and the idea of a homeland. Until now, the Jewish diaspora is the most commonly used example to explain the concept of a diaspora (see Butler, 200I; Bruneau, 20Io). The Chinese 
diaspora is one example that is often used to explain the diaspora. Chinese Diaspora occurs because the geographical conditions were not proportional to the large population of China so that some residents left and looked for work in new areas outside (see Lee, I966; Faist, 2010). Hence, the Chinese can be found in many places.

According to Wahlbeck (2000: 229-230), the concept of the diaspora can be developed into four forms. The first is geographical displacement and identity deterritoralization. According to this concept, diaspora is a caused of activities that unite new people in an area, regardless of their ethnic background. This concept is often referred to as diaspora as consciousness. The second is as a mode of cultural production, diaspora is formed through the

formation of a culture that exists in society. The third is political dimension of contemporary diaspora. Through the political dimension, the diaspora is seen from the political activities and relationships in the diaspora, both with homeland and its hosts; Fourth, diaspora is seen as a form of social organization. The last concept, is similar to the grouping of the four poles of the diaspora described by Bruneau (20I0). Diaspora, seen based on of social organizations that are related between homeland and its host ${ }^{\mathrm{I}}$.

Although initially the concept of the diaspora was known to explain the Jewish diaspora, in its development, the diaspora can be used to explain many things related to the transfer of a nation from a homeland (Faist, 20I0). Rudolf (2016) applies the concept of diaspora as an analysis tool to explore the meaning of identity of Senegalese people who have long lived in the Gambia. Dual identity cards become a differentiating tool for Senegalese people who have long settled in the Gambia when returning to Senegal. The Senegalese Diaspora are regarded as criminals who only want to take advantage of countries. On the other hand, Brian Keith Axel (2004) tries to describe the diaspora arising in

I The four poles of the diaspora according to Bruneau (2010) namely, based on religion, business activities, politics, as well as a combination of culture and race. a virtual community that builds on the same historical suffering of a hometown through the context of Sikh art expression spread across the virtual universe. For Axel himself, the diaspora is no longer about ancestral lands but how a sense of belonging among Sikhs who experience the same suffering throughout the world can be formed and maintained in a community.

In the context of Indonesia, Javanese, who has long lived by generations in Suriname, is the example of diaspora from Indonesia. The Javanese Diaspora in Suriname occurred during the Dutch occupation of Indonesia. At that time, starting in I880, the Dutch colonial government lacked plantation labor for their colonies, one of which was Suriname. Then, some selected Javanese were placed in plantations in Suriname to help. Unfortunately, the Javanese who were stationed in Suriname were not returned to their native lands even though Indonesia had already gained independent. The Javanese then settled and continued their lineage in Suriname. Until now, these people still maintain Javanese cultures, such as Javanese (Allen, 2015).

The concept of diaspora is developing, and its meaning extends in many directions (Brubaker, 2005: I). Brubaker stated that the diaspora could be seen through its collectivity, process, and being a position/attitude. When diaspora seen from the collectivity means togetherness that exists in a society claiming to be a diaspora. However, as a process, diaspora is seen on how the society is formed. Then, the diaspora can also be seen as the position/ attitude of the people who are members of it.

According to Butler (20II), diaspora has four characteristics. First, the community spread in the diaspora is more than in two locations, if only in one location it can be categorized into just migration. Diaspora spreads to the locations outside their home regions and formed communities there, for example is Chinese diaspora in Indonesia, United States of America and Australia. In Indonesia, the chinese diaspora generally can be divided into 'Peranakan Chinese' and 'Cina Totok', who came in between early fifteenth century and mid-nineteenth century (Brahma, 20I8). In the US, it is noticeable ac- 
cording to the census in 2000 the number of Chinese American was 2.7 million ( $\mathrm{Zhu}, 2007$ ). Meanwhile, in Australia, the chinese diaspora first came by the gold rush and mining boom in the mid-nineteenth century (Kuo, 20I3).

The second characteristic is that the community have ties to their homeland, both imaginion and reality. The point is that each diaspora is aware of the roots of the area of origin, both those that have physical territory and those that do not have physical territory such as the Jewish diaspora that does not have a physical homeland. In the simple way, diaspora can be explained based on the position of home and host. Home is the area of origin or homeland of the diaspora and then the host is the destination or current place of residence. Some articles try to explain the identity of the diaspora through the relationship between home and host. Firstly, Sheng Ding (2008) who wrote about the Chinese diaspora, stated that the power of the internet which finally built awareness to care about the condition of China as their homeland. Secondly, Changzoo Song (2014) describes the Chajonwok (Korean-Chinese Diaspora) who tried to earn a fortune back to South Korea as their home country. Song managed to clearly illustrate how the relationship between China (host) and South Korea finally shaped the image of Chajonwok in the eyes of South Koreans who always settled there. Thus, the concept of a nation's diaspora can be explained through the interrelationship between home and host which ultimately forms a sense of belonging between them.

The important characteristic of the diaspora is the sense of belonging when the people with full respect acknowledge themselves as part of the diaspora group. Aihwa Ong (2003) described the Cambodian refugee diaspora in California who entered America in the early I970s. These Cambodian refugees tried to hide their 'buddha' identity because at that time Buddhism was identical to the Khmer group led by Pol Pot who was known to have an ideology at odds with the United States. The Buddhist identity that is incorporated into the activities of the Mormon church and the ways in which they can become citizens of the United States who actually belong to them. Then, Ong (1993) also wrote about the Chinese diaspora that reconstructed their cultural belonging based on personal family ties that they felt when they wanted to achieve citizenship in Hong Kong.

As it is stated above about the concept and characteristic of diaspora from Walhbeck (2000), Faist (2010), Brubaker (2005) to Bruner (20II) it can be seen that diaspora is used in many ways. However, the making of diaspora can only be manifested from people within. The identity appears because the people are aware of and also wear it. Regardless of how far they were from their origin home, the Cambodianese (Ong, 2003) could made their cultural belongings, while the Chinese diaspora can be united in the virtual world to support their homeland (Sheng Ding, 2008). Diaspora is not only a spread of people with the same descendants but also as an acknowledgment of identity and a sense of belonging in the group. The connection between the area of origin (home) and the current area of residence (host) is still important to look at, but is not the main point.

\section{INDONESIAN DIASPORA IN THE HISTORICAL CONTEXT AND THE SENSE OF BELONGINGS}

Butler (200I) stated that there are four characteristics of diaspora: (I) having a distribution of more than one region and can only be considered a diaspora if it meets certain conditions, including (2) there is an attachment to homeland, (3) there is a feeling of mutual ownership between its members and finally (4) has a historical-temporal dimension and can only be categorized as a diaspora starting from the second generation. However, only the third category of Indonesian diaspora classification that matches with the diaspora concept. Then what about the other categories? In category one, conceptually Indonesian citizens who are temporarily settled abroad can only be considered as temporary exiles or people who are exiled for a certain time. Category two includes Indonesians who have renounced their citizenship as foreign nationals, these people can still be considered as diaspora in view of their descendants' roots. 
The aspects of time and identity are still relevant to be discussed to explain the Indonesian diaspora. Moreover, these aspects are risen by Dinno Patti Djalal, a former Indonesian ambassador in the United States as the founder of the Indonesia Diaspora Network (IDN). Djalal examined that the problems of the diaspora were different with what he found in the field. For Djalal and IDN, the concept of the diaspora governed by the Indonesian Presidential Regulation No. 76 of 2017 is in line with the concept of Indonesian diaspora by IDN. Furthermore, he proposed Indonesianists as a new category of the Indonesian diaspora. Although Indonesianist is not Indonesian descent he considered that Indonesianist' love for Indonesia as an important point, hence they could be considered as part of the Indonesian diaspora.

The aspects of love and sense of belongings could be the main characteristics in order to identify who is Indonesian diaspora. The sense of love and belonging is formed from the process of adapting and reckognizing identities which could lead the people to enter and leave the community. The main argument emerging is that not all Indonesians who live abroad have love or attachment to Indonesia. However, the government cannot close their eyes to this, especially for those who later decide to become foreign citizens, do they change citizenship solely for a better economic life or do they want to get rid of the bad memories they got as Indonesians?

Nonini (2006) in his writing about Indonesians of Chinese descent who later settled in Australia because they did not want their children and grand children to be victimized as what they experienced in the May 1998 case. The same experiences of suffering they felt in the May I998 case, made them unite in Australia. The historical suffering of the May I998 incident became a binder and an identity that they formed there. The Indonesians of Chinese descent who later settled in Australia identified Indonesia in the context of their suffering. The same problem comes from the next generations from the victim who accused as a communist in I965. They forced to went out because they were in jeopardy. Furthermore, do they still want to be considered as part of Indonesia or not?

In a discussion, one of Indonesia's longtime residents in Singapore, Ms. Monique Patricia, said that there were some of her acquaintances decided to change citizenship because of the many benefits they gained from other citizenships. Some foreign nationals of Indonesian descent usually do not want to join the Indonesian community for various reasons, for example they feel more as non-Indonesians and feel that non-Indonesian citizenship is more beneficial. Furthermore, according to Ms. Monique Patricia, spokesperson for the Indonesian Diaspora Network, Indonesian citizens who have become foreign citizens or Indonesian descendants cannot be measured in how deep their love and attachment to Indonesia is.

"I, myself, am still a native Indonesian citizen, not necessarily, for example, Calvin (one of the researchers at IDN), become the foreigners, then how can we measure his love for Indonesia?.."(private interview, June 28th, 2018)

The existence of diaspora in the world cannot be separated from the historical and the sense of belonging aspects. History is used as an analysis tool to find out the reasons for the diaspora leaving their homeland (see Ong, 2003; Ong, 1993). While the aspect of sense of belonging reconstructs the arguments for the development of the life of the diaspora in the new place of residence and how the identity is attached to the diaspora. Both of these aspects become interested in seeing the relevance of the connection between homeland and host.

The author tried to see the awareness of the identity and sense of belonging for the Indonesian diaspora who have returned and accepted to work at one of the research centers in Indonesia. It is turned that some of them understand that they are called as Indonesian diaspora, since they had lived overseas for some years. However, they did not really sure what diaspora is, except the fact of they had lived abroad. Staying for a certain time abroad has made them a diaspora, on the other hand some of them consider themselves as not a 
part of the diaspora, they are only Indonesian citizens who happen to study and live temporally abroad. They feel that they are still part of Indonesia because of the participation of the Indonesian community in their country of learning (host). Indonesian communities abroad make them feel at home even though they are far from Indonesia, including by holding charity activities, cultural actions and religious activities. Moreover, they feel that what they do abroad will bring Indonesia's good name to the world. This is an attachment to identity as an Indonesian citizen. However, it should be remembered that they were only temporarily living abroad, their memories of Indonesia and their attachment to the government remain the same because of the relatively short time.

\section{INDONESIAN DIASPORA OR JUST INDONESIAN MIGRANTS (?)}

If the first generation of Indonesian community groups abroad is still considered relevant to be included in the Indonesian diaspora category, the next question is whether these groups have been united because of the bond of consciousness as Indonesians? Are they united because of the same nation background or of the other identities, such as ethnicity and religion?

One of the well-known Indonesian diasporas is the Javanese diasporas in Suriname who was initially forced to leave Java because the Dutch colonial government needed workers in Suriname (see Allen, 2015; Muftakhin, 2016). The Javanese in Suriname then settled and maintained their identity as Javanese there. The case of the Javanese in Suriname has a historical aspect that is out because the coercion of the colonial government and sense of belonging are maintained with their 'Javanese' identity.

Indonesian community groups abroad had existed long before the Indonesian Diaspora Network (IDN) was declared in 2012. The groups are gathered from various background, such as Bugis migrants in Turkey, Christian Community in Singapore, and the Indonesian Student Association in the Netherlands. All of these groups have their own goals and awareness of ties that differ from one another.
Indonesia is formed from a diversity of identities including ethnicities and religions. This diversity arises as binding on community groups in Indonesia. The same way as in Indonesia, Indonesian community groups abroad have their own uniqueness due to the stronger identity ties come from ethnic or religious similarities. Certainly, the diversity of groups also gave rise to a variety of visions from these different groups. Moreover, Dino Patti Djalal said that what he found when he was the ambassador in the United States was an interesting experience of how little identities formed different sentiments between groups.

When I was in America, the groups were very funny, too many petty things, for example I came to one church (Indonesian) Christmas event, the other was angry. Not only that, on Eid too. I pray at this mosque, there are people (Indonesians) who are angry at other mosques (August 29, 2019).

From the statement above, it can be seen that the Indonesian diaspora's belonging can not be found similarly in all groups of Indonesians overseas. Some groups made theirs based on specific backgrounds, such as the ethnicity or religion. It seems that Indonesian identity is not the main concern of the groups.

\section{Bring back Indonesian Diaspora: Cases of Arcandra Tahar and The Sentiment of Being Indonesian}

The appointment of Arcandra Tahar as a Minister of Energy and Mineral Resources in 2016 caused controversy in Indonesia. This happened since Arcandra had an Indonesian passport and an American passport. Arcandra was found guilty of not informing the ownership of a US passport when he was to be appointed Minister of Energy and Mineral Resources by President Jokowi. However, what was interesting to note besides passport ownership was how the negative response was formed on this issue. In the national news page of the House of Representatives, one of Commission III members, Dwi Ria Latifa said that the problem of Archandra's dual passport had hurt the feelings of other Indonesian citizens who can comply with procedures 
well. Then, Latifa added whether there were no other candidates for the position without having to go through problems as Arcandra did. Latifa's comments were one example of expressions of Indonesian citizen rejection of the assignment of Arcandra.

On the other hand, the 'rejection' not only came from the general people, some scholars in Indonesia thought that the return of the Indonesian diaspora has no point. Since if they do not have to come back in order to support Indonesia, instead they can use their network where they recently lived to make investments in Indonesia.

"I thought it is not necessary for the government to return them (diaspora) back because we have to prepare where they can work in Indonesia, means the competition is getting tougher, yet many Indonesians still need a settle work for their live. However they still can send the remittances to Indonesia or just put their investments in Indonesia.-(private interview, August 29 $9^{\text {th }}$ 20I8)"

The case above illustrates that there is still sentiment towards Indonesian citizens who are abroad, plus Arcandra is not blunt about the ownership of the two passports.

Problems with the rejection of the diaspora to return to their homeland, as Arcandra, occurs as well in other countries. Changzoo Song (2014) in his writings about the discriminatory treatment of South Koreans against Chosonjok which is a South Korean who moved to China during the South Korean war with China. South Koreans consider Chosonjok to be the same as Chinese and is treated unfairly. Starting from immigration, monitoring the entry of Chosonjok was tightened. After successfully entering and finding work in South Korea, the Chosonjok received lower wages than other workers. The discrimination did not stop there, Chosonjok men were even portrayed as rude people in tv dramas.

Arcandra's similar case might be repeated with the plan to summon the Indonesian diaspora abroad to return and serve. In addition, the recall of the diaspora in Indonesia is accompanied by a discourse on salary adjustments in accordance with his experience abroad. The reason is due to there are Indonesians who still stand against the plan to bring the diaspora back to Indonesia and argue that the people in Indonesia are still competitive. For this reason, this plan needs to be considered very carefully, especially if the diaspora called back has already become a foreign citizen, of course there will be many regulations that need to be reviewed and there may be protests in the country.

\section{INDONESIAN DIASPORA AND ITS POTENTIAL FOR INDONESIA}

Apart from the acceptance problem of the diaspora, it has some potential contribution for the motherland as well. The Indonesia Diaspora Network, for example, has successfully initiated several export collaborations from Indonesia and introduced Indonesian culture in festivals conducted overseas. Aside from these visible activities, the existence of Indonesian diasporas can be an extension of the expansion of Indonesian products and open investment opportunities, Muhidin and Utomo (2015: 9-IO) summarize five potentials can be given by Indonesian diaspora abroad:

I) Firstly, remittances from expatriates have been demonstrated to be a larger and more reliable source of development funds than the official development assistance from donor agencies such as the World Bank (Mohapatra, Ratha and Silwal 20II).

2) Secondly, the diaspora can be both a direct source of Foreign Direct Investment (FDI) and an effective 'middleman' to channel FDI towards the home economy. Lucas (2003) in his study shows how the chinese diaspora has contributed about $60-70 \%$ of $\mathrm{FDI}$, as the biggest in the world.

3) Thirdly, the diaspora can be a bridgehead into the expansion of the economic linkages of the home nation. Korean Americans were the bridgeheads for the successful penetration of the United States market by Korean car, electronics and white good manufacturers.

4) Fourthly, diaspora networks have become important in transmitting information both formally and informally. This 
dimension is largely confined to skilled migrants. Lucas (200I, 22) has shown how professionals in origin and destination economies have maintained strong linkages so that ideas flow freely in both directions.

5) Fifthly, many expatriates return to their homeland country and contribute to development (Conway and Potter, 2009).

It is stated that there are some potentials from the diaspora. However, four potentials do not require the diaspora to return back home. Therefore, the Indonesian diaspora should not be returned in order to make their potentials and the Indonesian government can learn from the other countries who had their diaspora overseas, such as Chinese and Korean. Learning from the Chinese and Korean diaspora, the diasporas of the two countries have managed to develop their country's economy well. The Chinese government for example succeeded in making investment policies (FDI) that are friendly to its diaspora coupled with making programs that focus on human capital and technology development (Chareonwongsak, 2012:3-7). The Korean government managed to regulate $80 \%$ of remittances from its diaspora in the Middle East and America to continue sending their money domestically (Lee, 2005). The Indian Diaspora has also succeeded in developing investments for the country through a government program through the Ministry of Overseas Indian Affairs and the Overseas Indian Facilitation Center (Tigau, et al., 20I7: I86-I88). These successes are of course preceded by clear policies regarding the entry of foreign investment and the regulation of the diaspora.

\section{THE RECOGNITION OF INDONESIAN DIASPORA THE TRANSFORMATION OF THEIR IDENTITY}

Out of all conceptual debates of the clasification and characteristics of Indonesian diaspora, there is an interesting thing to be pointed out, that the Indonesian government has different perspectives to define Indonesian diaspora and there is a transformation of identity labeled for Indonesian diaspora. The Indonesian government has made a formal practical criteria to make a list of Indonesian diaspora. It would be difficult homework for them to register the number of the second or maybe the third generations of Indonesian diaspora and so on. Furthermore, by time goes, there is a transformation in the Indonesian diaspora identity. The long period of residency or the number of generations becomes the second thing for the registration. As long as someone has been living in foreign country within a temporary time, they will be labeled as Indonesian diaspora.

The identity transformation of the Indonesian diaspora is also seen through the input of Dino Patti Jalal who considers Indonesianist as a part of the Indonesian diaspora. Love and sense of belongings are considered important factors in defining the Indonesian diaspora. Although considered as wild, the idea of incorporating Indonesianists into Indonesian diaspora groups is a form of transformation from the classic diaspora concept that sees the importance of the bond between home and host. This bond is used as an Indonesianist justification for being an Indonesian diaspora.

Moreover, to classify Indonesian diaspora, sense of belongings can not be dettached from the recognition and historical background of the people. To be listed as Indonesian diaspora, someone has to recognise themselves as Indonesian diaspora or have something to be claimed that they love Indonesia. Similar to what Dino Pati Jalal offers in IDN, some Indonesianists already declared their emotional attached with Indonesia through their works. Moreover, they love to promote Indonesia in the international sphere. In contrast, historical background can lead the people to loose their emotional attached with Indonesia. Nonini's example of the migrant victim of the I998 act shown that painful memories should be considered to define Indonesian diaspora. Recognition and emotional belongings become the important things for Indonesian diaspora since the government still hopes for their contribution to Indonesia. 


\section{CONCLUSION}

Akin to the theory of identity, diaspora is a flexible thing that can be used in many ways. To some extend its definition can not be judged as an absolute meaning. What has the Indonesian government done in the Indonesian Presidential Regulation No. 76 of 2017 was a practical way to make a clear definition of the diaspora was not wrong. It was clear that the regulation was opened a way for the Indonesian diaspora to contribute to the country. Yet, the Indonesian government could not be forced the people to acknowledge themselves as Indonesian diaspora.

However, for the author, the important thing about the Indonesian diaspora was the recognition and emotional belongings of the people. It was impossible for Indonesia to get the contribution from the diaspora, and would be stopped at the registration step without any real progress, unless the government paid attention for their emotional belongings. Nevertheless, there are various ways to see the meaning of the Indonesian diaspora, and there is no need to say if the one is right or wrong. All of the perspectives reflects different interests, such as the meaning from the official regulation and the IDN concept.

Furthermore, the potential presence of Indonesian diaspora abroad should also be a consideration for advancing Indonesia. The Indonesian Diaspora also has the potential to be a path for the development of domestic investment and knowledge sharing. However, the government's plan to call the Indonesian diaspora back into the country needs to be carefully prepared because, for now, when the Indonesian diaspora returns, it will even tighten the competition of the Indonesian population to find prosperity. Therefore, the Indonesian government must pay attention carefully to whatever the decision to be made for the Indonesian diaspora because it could affect the development of the country.

\section{REFERENCES}

Allen, P. (2015). Diasporic Representations of The Home Culture: Case Study from Suriname and Caledonia. Asian Ethnicity, I-I9.

Axel, B. K. (2004). The Context of Diaspora. Cultural Anthropology, 26-60.

Baumann, Z. (1989). Holocaust. Cambridge: Polity Press

Brahma, S. (2018). The Position of Ethnic Chinese in Indonesia. Impact Journal, 269-276

Brubaker, R. (2005). The 'diaspora' diaspora. Ethnic and Racial Studies, I-I9.

Bruneau, M. (20I0). Diaspora, Transnational Spaces and Communities. In R. B. Faist, Diaspora and Transnationalism: Concepts, Theories, and Methods (pp. 35-49). Amsterdam: Amsterdam University Press.

Butler, K. D. (200I). Defining diaspora, refining a discourse. Diaspora: a journal of transnational studies, I89-2I9.

Faist, T. (2010). Diaspora and transnationalism: what kind of dance partners? In R. B. (eds.), Diaspora and Transnationalism: Concepts, Theories, and Methods (pp. 9-34). Amsterdam: Amsterdam University Press.

Ite, U. E. (2002). Turning Brain Drain into Brain Gain: Personal Reflections on Using The Diaspora Option. African Issues, 76-80.

Kuo, Mei-fen. (2013). Making Chinese Australia: Urban Elites, Newspapers, and the Formation of Australian Chinese Identity, I892-I9I2. Melbourne: Monash University Publishing

Lee, E. (I966). A Theory of Migration. Demography, 47-57.

Lee, H.-K. (2005). The Korean Diaspora and Its Impact on Korea's Development. Asian and Pacific Migration Journal, I49-I68.

Muftakhin. (2016). Islam Jawa in Diaspora and Questions on Locality. Journal of Indonesian Islam, 375-394.

Muhidin, S., \& Utomo, A. (2015). Global Indonesian Diaspora: How many are they and where are they? Journal of ASEAN Studies, 93-IOI.

Nonini, D. M. (2006). Indonesia Seen by Outside Insider: Its Chinese Alters in Transnational Space. Social Analysis: The International Journal of Social and Cultural Practice, 214-225.

Ong, A. (1993). On The Edges of Empires: Flexible Citizenship among Chinese in Diaspora. Positions: Asia Critique, 745-778. 
Ong, A. (2003). Budha is Hiding: Refugees, Citizenship, The New America. California: University of California Press.

Rudolf, M. (20I6). Identity beyond ID: Diaspora within Nation. In J. Knor, \& C. Kohl, The Upper Guinea Coast in Global Perspective. New York: Berghan Books.

Song, C. (2014). Politics and The Meaning of Homeland Among Korean Chinese Migrants in South Korea. Urban Anthropology and Studies of Cultural Systems and World Economic Development, 44I-479.

Tigau, C., Pande, A., \& Yuan, Y. (20I7). Diaspora Policies and Co-development: A Comparison between India, China, and Mexico. Migration Letters, I8I-
Wahlbeck, O. (20I0). The Concept of Diaspora as an Analytical Tool in The Study of Refugee Communities. Journal of Ethnic and Migration Studies, 22I-238

Zaenuddin, D., Maunati, D., Rucianawati., \& Wiratri, A. (20II). Diaspora Bugis di Sabah, Malaysia Timur. Jakarta: LIPI Press

Zhu, Z. (2007). Two Diasporas: Overseas Chinese and Non-resident Indians In Their Homelands' Political Economy. Journal of Chinese Political Science, 28I-296 